\title{
Atemschaukel: um soluço faminto e o mover- se para sobre-viver
}

\author{
Gerson Roberto Neumann e Cláudia Fernanda Pavan*
}

\section{Introdução}

O tradutor é, ao mesmo tempo, receptor e produtor: descobre e interpreta um texto e produz outro. Entretanto, a tradução não se limita à leitura e interpretação de um texto e sua retextualização na língua de chegada: ela pressupõe uma decisão entre duas ou mais possibilidades, concretas e legítimas, de interpretação do texto de partida, uma decisão sempre marcada pela subjetividade do tradutor, que está, inevitavelmente, associada à sua cultura, suas crenças, suas vivências e aos objetivos da tradução.

O presente trabalho, uma análise de duas traduções do título Atemschaukel, de livro de Herta Müller, parte do que dizem alguns estudiosos sobre o tradutor e a tradução, o leitor de um modo geral, o leitor de uma tradução e o tradutor como leitor.

Baseando-nos no texto do romanista alemão Ottmar Ette, "Com as palavras do outro. O tradutor notável é um excelente mentiroso", pode-se tomar a tradução não apenas como uma ponte entre culturas diferentes, mas como produção e inter-relação de diversos aspectos, pois

\footnotetext{
o texto do tradutor só pode captar nas palavras da língua de chegada aquilo que é imaginável ou pelo menos se encontra nas fronteiras do imaginável nela. A mentira estrutural representa o preço que a cultura tradutora precisa pagar caso queira ampliar suas próprias possibilidades de pensamento, e por conseguinte suas formas de expressão filosóficas, literárias e artísticas. (Ette, 2010, p. 19)
}

\footnotetext{
* Gerson Roberto Neumann é Professor Adjunto de Germanística da Universidade Federal do Rio Grande do Sul. Cláudia Fernanda Pavan é graduanda no curso de Letras Português-Alemão da Universidade Federal do Rio Grande do Sul.
} 
Segundo Micotti (2012, p. 11), no livro Alfabetização. Propostas e práticas pedagógicas, o leitor desempenha papel ativo no processo de criação de sentido do texto. Essa ação, entretanto, quando vinculada a um texto traduzido, não depende unicamente do que foi escrito pelo autor do texto de partida, mas da leitura, da interpretação realizada e do novo texto produzido pelo tradutor.

De acordo com Nunes (2011, p. 16), no texto “Do bilíngue ao tradutor, do enunciado à enunciação: notas sobre uma perspectiva enunciativa do tradutor e da tradução", a leitura do tradutor não se limita à leitura da forma, mas é a leitura da formação de um sentido, aquele "que o tradutor concebe como o sentido do texto original." E o ato de conceber um sentido encerra, irremediavelmente, uma escolha, por parte do tradutor, entre diversos sentidos possíveis. Uma tradução não é, jamais, imparcial ou desinteressada, ela tem um propósito; as palavras escolhidas pelo tradutor nunca são inocentes, elas encerram uma intenção.

Ao ler "Digressão sentimental sobre Oswald de Andrade" (Candido, 1970), pode-se supor a tradução como um ato antropofágico: precisamos devorar e digerir o outro texto, a outra língua, a outra cultura, para então recompô-los através da tradução. Da mesma forma que para os modernistas o movimento antropofágico era visto como um movimento crítico e de transformação, assim também podemos definir a tradução. Enquanto comparada à arte, é possível percebê-la não apenas como um processo crítico e de transformação, mas também como um processo criativo.

O conceito de antropofagia é especialmente adequado ao texto de Herta Müller. A própria autora manifestou em entrevista a König, J., em 2012, ao falar sobre seus livros, esse aspecto do seu relacionamento com a língua, ao dizer: "eu já tinha 15 anos quando aprendi a língua [romeno], e era como se eu a comesse. Ela era saborosa, não tenho como dizer isso de outra maneira" (2012) ${ }^{1}$

O estilo de Herta Müller é ímpar. Segundo Neumann (2013), a obra da autora

\footnotetext{
1 "als ich die Sprache [Rumänisch] gelernt habe, war ich schon 15, es war, als würde ich sie essen. Sie hat mir geschmeckt, ich kann es nicht anders sagen". (Tradução nossa)
} 
caracteriza-se pelo pensar entre-mundos, pelo constante diálogo com o outro, numa constante busca por algo e/ou por algum lugar. As personagens em Müller caracterizam-se pela constante busca, levando consigo tudo o que têm e que podem carregar (a língua, a memória, os símbolos).

A partir dessas reflexões, como já indicado, pretende-se analisar duas traduções do título de um romance de Herta Müller, Atemschaukel, considerando as escolhas dos autores da tradução portuguesa e da brasileira.

Para situar o leitor, apresentamos uma breve bibliografia da autora e, em seguida, um resumo do livro.

O pai de Herta Müller era oficial da SS quando a Romênia se aliou à Alemanha, na II Guerra Mundial. Pouco antes do fim da guerra, a Romênia mudou de posição política, passando para o lado da URSS. Quando Stalin ordenou o envio de milhares de romenos de origem alemã para os campos de trabalhos forçados, a mãe da autora estava entre eles.

Herta Müller nasceu em 1953 em Nitzkydorf, na região do Banato, uma região de minoria de emigrantes alemães, dividida hoje entre Romênia, Sérvia e Hungria. Entre 1973 e 1976, estudou literatura alemã e romena na Universidade de Timisoara, na Romênia, e fez parte do Aktionsgrupp Banat, um grupo de jovens de oposição ao regime de Ceausescu e que defendia a liberdade de expressão. Depois de terminar os estudos, trabalhou como tradutora numa fábrica de máquinas, de 1977 a 1979. Foi despedida por ter se recusado a ser informante da polícia secreta. Proibida de publicar na Romênia por ter criticado publicamente o regime de Ceausescu e por se negar a contribuir com a polícia, a escritora emigrou em 1987 para a Alemanha com o marido, o poeta Richard Wagner, também nascido na Romênia. Em 2009, Herta Müller publicou o romance Atemschaukel e, nesse mesmo ano, recebeu o Nobel de Literatura pelo conjunto de sua obra.

O livro Atemschaukel é baseado nas experiências do poeta romeno, de origem alemã, Oskar Pastior, amigo de Herta Müller que, assim como a mãe da escritora, fora deportado para um campo de trabalhos forçados logo após o fim da II Guerra Mundial. Leo Auberg é um jovem de 17 anos, homosse- 
xual (em um país onde a homossexualidade era tida como crime), que costumava passar suas tardes em encontros misteriosos com outros homens que sequer podiam revelar sua real identidade. Em janeiro de 1945, Stalin exigiu que todos os alemães residentes na Romênia contribuíssem para a "Reconstrução" da União Soviética, destruída durante a guerra. O ditador tinha a convicção de que os grupos germânicos daquela região haviam contribuído com Hitler durante a II Guerra Mundial e como castigo qualquer um (homem ou mulher) com idade entre dezessete e quarenta e cinco anos era enviado para um gulag. Segundo Leite (2012), em "Além da tortura", a maioria dos prisioneiros desses campos morria ou enlouquecia e os que sobreviviam eram "verdadeiras testemunhas do inferno". Leopold Auberg tem 17 anos, é romeno de origem alemã e se encaixa, portanto, no perfil daqueles que são enviados para os campos de trabalhos forçados. Assim, o livro relata, em grande parte, suas experiências em um desses gulags: o frio, os maus tratos, o trabalho forçado e, principalmente, a fome. As únicas coisas que trazem um pouco de esperança ao jovem são os livros que lê (posteriormente vendidos em troca de um pouco de sal ou açúcar), as lembranças de sua infância e a profecia da avó: "Eu sei que você vai voltar". Leo conta a história sessenta anos depois de sair do campo de trabalhos forçados e, além de tudo o que sofreu lá, narra a volta para casa e a dificuldade de retornar ao cotidiano familiar.

Levando em consideração o conhecimento especializado apontado por Albir (2005, p. 21), em “A aquisição da competência tradutória: aspectos teóricos e didáticos", julga-se importante conhecer, ao menos um pouco, os dois profissionais cujas traduções serão analisadas. Não apenas com o objetivo de oferecer mais informações que ilustrem a "competência tradutória" discutida por Albir, mas também com a intenção de evidenciar, mesmo que brevemente, o perfil e o trabalho desses profissionais.

Carola Saavedra (Santiago, Chile, 1973) é romancista e contista. Aos três anos de idade, mudou-se com a família para o Brasil, fixando-se no Rio de Janeiro. Na infância e na adolescência estudou em um colégio alemão. Na década de 1990, após se formar em jornalismo, foi para a Europa, morando na Espanha, França e Alemanha, onde conclui mestrado em comunicação social. Embora trabalhe como tradutora de alemão e espanhol, sua atividade 
principal é a de escritora. Ela mesma, entrevistada por Kristina Michahelles para a revista Humboldt por ocasião da escolha do Brasil como país-tema na Feira do Livro de Frankfurt em 2013, diz: "Não sou tradutora. Sou uma escritora que traduz. [...] Traduzo apenas quando o livro me interessa, quando vejo ali uma possível aprendizagem. Meu interesse é pela literatura, não vivo da tradução." Ainda sobre seu trabalho como tradutora, ela afirma, em entrevista a Ramon Mello (2010):

\footnotetext{
Há quem diga que o tradutor recria a obra. Eu penso que não, tento me manter a mais fiel possível ao autor. Há momentos que se manter fiel pode ser um risco, pode ser estragar o trabalho. Mas não me vejo como autora quando traduzo. Sou autora quando escrevo meus livros.
}

Ramon Mello declara, no prólogo dessa entrevista, realizada para o site Saraiva Conteúdo, em 2010: “A delicadeza das palavras de Carola emite o eco de autoras como Clarice Lispector e Lygia Fagundes Telles". Saavedra, contudo, esclarece, no debate "Sobre a escrita de si e a escrita do outro", realizado durante o Salão do Livro em Paris (2015), com as escritoras Conceição Evaristo e Adriana Lunardi, que, embora tenha lido com intensidade a obra de Clarice Lispector, seu projeto literário não possui uma relação clara ou mesmo necessária com a obra da autora de A maçã no escuro.

Sobre a tradução do livro de Herta Müller, Saavedra afirma em entrevista para a Homo Literatus (2014): “Tudo o que tenho levo comigo é uma grande obra, em termos de narrativa, de linguagem, a Herta Müller é antes de tudo poeta, e isso você percebe ao ler o romance. O livro exige a recriação dessa linguagem, dessa atmosfera."

Tudo o que tenho levo comigo foi o único livro de Herta Muller traduzido por Carola Saavedra. Além dele, ela também traduziu para o português Morte de Tinta (Tintentod, 2010), de Cornelia Funke, escritora alemã de literatura infanto-juvenil.

Aires Graça é docente da Universidade Nova de Lisboa e integra a Associação Portuguesa de Estudos Germanísticos. Já traduziu diversas obras do alemão, entre elas, o livro A pianista, da escritora austríaca Elfriede 
Jelinek, vencedora do Prêmio Nobel de Literatura em 2004, poemas de Bertold Brecht e, além de Tudo o que eu tenho trago comigo, outros dois livros de Herta Müller: Hoje preferia não me ter encontrado (2011) e Já então a raposa era o caçador (2012). Aires Graça também escreve diversos artigos nos quais se ocupa de questões referentes à tradução, entre os quais "Cultura, tradução e vivência do significado" (2002), "Cultura e tradução: o contexto cultural como categoria translatória" (2003) e "Interpretação e tradução: a infidelidade como virtude" (2011).

Em "Cultura, tradução e vivência do significado", Graça aborda aspectos importantes relacionados à teoria tradutória, dando destaque à articulação entre a tradução e os aspectos culturais que envolvem tanto o texto de partida quanto o texto de chegada:

\footnotetext{
Do ponto de vista da prática de tradução, a cultura é, num sentido mais lato, o lugar do conhecimento intersubjectivo que permite actualizar, cada vez com mais eficácia, uma relação de equivalência interlingual. A cultura permite intuir, reconhecer, experimentar ou investigar os hábitos linguísticos e extralinguísticos, as idiossincrasias e os mecanismos inconscientes que podem estar por detrás da produção e recepção do texto de partida e do texto de chegada. Este lugar de operacionalidade é componente insubstituível da competência do tradutor. (grifos do autor) (Graça, 2002)
}

Em "Interpretação e tradução: a infidelidade como virtude", como veremos adiante com mais detalhes, Graça analisa algumas das escolhas que fez na tradução de Atemschaukel, permitindo-nos entrever as reflexões que guiaram suas decisões. Nesse texto, podemos acompanhar um pouco as questões envolvidas no processo de tradução, os desafios enfrentados e os recursos utilizados por ele na produção do texto para a língua de chegada.

\section{Análise das traduções dos títulos}

A linguagem utilizada por Herta Müller é forte, porém contida. Segundo Rufino (2012), em “Prémio Nobel Herta Müller: 'A realidade incita-me a escrever pelo lado que me agride'”, "a produção literária de Herta Müller alimenta-se do medo e do profundo desenraizamento da escritora. [...] Nos seus 
livros, Müller interroga tudo de forma dura, tensa e sem piedade. A escrita incide sobre elementos que a repulsam."

Herta Müller faz uso de muitas metáforas, personificações e cria muitas palavras - o que é bastante comum na língua alemã, mas pode trazer dificuldades à tradução para a língua portuguesa. Já no título do livro é possível verificar a dificuldade de tradução referente à criação de palavras no alemão: Atemschaukel, literalmente, significa "balanço da respiração". Contudo, a impressão que se tem, no decorrer da leitura do livro, é a de uma respiração sempre contida, curta, crispada, com medo, nunca completa. A palavra "balanço" expressa, geralmente, uma ação suave, leve, gostosa, e que não traduziria, com a intensidade adequada, a respiração que testemunhamos, que quase experimentamos ao ler o livro. Assim, "balanço da respiração", embora seja a tradução literal, não dá conta de expressar todos os sentidos condensados em Atemschaukel.

A composição de palavras no alemão é um recurso muito produtivo e acentua ainda mais a forma econômica e sóbria da escrita de Herta Müller. Além disso, podemos considerar a composição de palavras, em especial a palavra Atemschaukel, como uma forma de ilustrar sentimentos que levam o personagem tão à beira da sua humanidade que de outra forma não seria possível explicá-los. Essa qualidade imagética intensifica o efeito que o texto exerce sobre o leitor e é uma das características mais marcantes do estilo de escrever da autora.

Cada um dos muitos capítulos do livro - alguns bastante curtos, outros mais longos - pode ser visto como um expirar e um inspirar, marcando a sobrevivência em um cenário de morte. Os capítulos são marcados por um movimento lento, porém constante, como uma respiração pesada, carregando-se o fardo de estar vivo em um cenário dominado pela morte, que é presença constante no dia a dia dos trabalhadores dentro dos campos de trabalhos forçados.

De acordo com Graça (2011, p. 11), Herta Müller, ao ser questionada quanto ao título do livro, disse que tirou o nome de um exercício de yoga que costumava praticar para aliviar o cansaço durante o período de pesquisas e entrevistas para a criação do romance. O exercício consistia em fazer 
expirações curtas, estendendo o corpo para frente enquanto sentada, voltando, ao inspirar, à posição inicial. Em outra oportunidade (entrevistada por Von Beyer, 2012), a autora afirma que já usava essa palavra em suas conversas com Oskar Pastior, mas não esclarece seu significado ou o contexto em que a usava.

Fica claro, portanto, que a tradução da palavra Atemschaukel impõe um desafio aos tradutores e a seguir analisaremos a solução de cada um deles para o título.

Ao pesquisar outras traduções para o título do romance, constatamos que, assim como no português (europeu e brasileiro), o título do livro em inglês também não é uma tradução literal do título original. Philip Boehm, que fez a tradução para o inglês em 2012, optou por The hunger angel, solução que nos parece também bastante adequada: essa personificação da fome é tão forte que há dois capítulos no livro intitulados "O anjo da fome".

Os dois tradutores para o português optaram por usar a primeira frase do romance como título: Alles was ich habe trage ich bei mir. Aires Graça discorre longamente sobre como se decidiu pela tradução do verbo tragen no título do romance para o português europeu:

\footnotetext{
"Tudo o que tenho carrego comigo" era o que constava da tradução. "Carregar" era até aqui a correspondência certa, porque se alude a um fardo, principalmente interior [...]. Mas, no titulo, o termo 'carrego' era demasiado duro [...].(2011, p. 11)
}

Mais adiante ele reflete sobre o uso do verbo "levar", mas não o considera adequado:

\footnotetext{
O verbo "levar" não funciona no texto, porque a sua repetição obrigatória resulta frouxa e equívoca: a associação a "não o levarás contigo" parece remeter para o outro mundo; "levo em mim" soa a "levar pancada" ou coisa ainda mais obscena; "levei tudo o que tinha" produz sonoridade de "lavei tudo o que tinha"; para além de não ter o peso nem a intimidade que o texto lhe atribui. (p. 12)
} 
As últimas palavras da citação acima nos causam certa surpresa, até mesmo um choque, pois, conforme Graça: "não tem o peso, nem a intimidade que o texto lhe atribui". A surpresa está relacionada principalmente ao título do livro em português brasileiro: Tudo que tenho levo comigo, enquanto a tradução escolhida por Graça, então, foi: Tudo o que eu tenho trago comigo. Segundo Graça, existe aí um movimento de fora para dentro, algo pessoal neste "trazer" e por ser mais íntimo carrega em si um sentido mais pesado, algo que está despido de leveza, assim como é o texto: o carregar de um fardo para se manter vivo.

\section{Trago comigo ou levo comigo?}

A partir das colocações, principalmente de Graça, passou-se então a examinar essas duas expressões que, até este momento, pareciam quase equivalentes. É possível afirmar que esses dois verbos têm em comum o sentido de transportar, ou, como mencionou Aires Graça, de carregar, de estar em movimento.

“Levar" implica certo distanciamento, implica entregar: levo alguma coisa que em algum momento chegará a seu destino e ficará lá, não mais comigo. Mas o que trago comigo, me pertence, está implícito que não vou deixá-lo em lugar nenhum. Há uma permanência em "trazer" - ou um peso e intimidade, nas palavras de Graça - que não há em "levar".

Essa diferença, que em uma leitura mais rápida pode passar despercebida, parece crucial após a leitura do livro. Há um "fardo" em "trazer comigo" que não é, em absoluto, igual a "levar comigo". E o fardo do personagem do livro é descomunal: tudo que ele tem, traz consigo. Ainda depois de sair do campo: o medo, a fome, a submissão que o acompanharam lá, continuam com ele. Ele os traz consigo, mesmo sessenta anos depois, ao contar sua história.

\section{Considerações finais}

Traduzir é uma tarefa complexa, subjetiva e fascinante e, como afirma Schnaiderman em Tradução, ato desmedido, é um ato destemido, é "elixir e veneno, néctar e fel, 'esplendor e miséria', na visão de Ortega y Gasset, júbilo e tormento, a tradução é dos atos capitais da vida humana" (2011, p.19). 
O objetivo nesta análise foi explorar as diferenças nas traduções do título Atemschaukel para o português. De acordo com Wills (apud Gentzler, 2009), a variabilidade que encontramos em textos traduzidos é "resultado dos diferentes contextos culturais em que os tradutores se encontram em suas decisões criativas, muito subjetivas." E segundo Ottmar Ette,

\begin{abstract}
a boa tradução não é nem traição nem engano, e sim - paradoxalmente uma mentira que expõe outras verdades ou as verdades do outro. Ela é uma ponte que concede chão seguro aos pés dos peregrinos entre dois mundos, mas sem fazer de conta que ela é, ela mesma, a terra firme. (Ette, 2010, p. 19)
\end{abstract}

A tradução de Atemschaukel é, sem dúvida alguma, um trabalho complexo e um dos motivos dessa imensurável complexidade é a linguagem utilizada por Herta Müller, uma linguagem que tem a missão de traduzir em palavras os sentimentos obscuros e incomparáveis que estão intimamente ligados à fome emocional e física de Leopold.

Não há como anular a distância - cultural, histórica, discursiva que existe entre o texto de partida e o de chegada; não há como anular o outro e, portanto, não há jamais transparência na tradução. A tradução de um texto é a produção de outro texto na língua de chegada e, como diz Meschonnic, em "Poética do traduzir, não tradutologia" (2009), o tradutor é "um criador, um transformador, um re-enunciador" que, ao traduzir, deixa suas próprias marcas no texto, como foi possível perceber nessa breve análise.

Reproduzir o discurso do outro é sempre parcial. Existe uma impossibilidade na tradução que é inerente à língua. Há sempre um elemento de intraduzibilidade, embora isso não inviabilize a tradução: é da natureza da língua não se deixar traduzir toda e é da natureza do tradutor enfrentar esse desafio.

\title{
Referências
}

ALBIR, A. H. A aquisição da competência tradutória: aspectos teóricos e didáticos. In PAGANO, A.; MAGALHÃES, C.; ALVES, F. Competência e tradução. Cognição e discurso. Belo Horizonte: Editora UFMG, 2005, p. 15-57. 
CANDIDO A. Digressão sentimental sobre Oswald de Andrade. In Vários escritos. Campinas: Duas Cidades, 1970.

ETTE, O. Com as palavras do outro. O tradutor notável é um excelente mentiroso. Tradução de Marcelo Backes. In Revista Humboldt, no ${ }^{101}$. Goethe Institut, 2010, p. 16-19.

GENTZLER, E. Teorias contemporâneas da tradução. Tradução de Marcos Malvezzi. São Paulo: Madras, 2009.

GRAÇA, A. Cultura, tradução e vivência do significado. In Revista Lusófona de Humanidades e Tecnologias, v. 1, no 6/7/8, 2002. Disponível em: <http://revistas.ulusofona.pt/index.php/rhumanidades/article/view/1457/1203>. Acesso em 30 de novembro de 2015.

Interpretação e tradução: a infidelidade como virtude. In Real Revista de Estudos Alemães, no 2, julho de 2011, p. 1-24. ISSN 1647-8061. Disponível em: <http://real.letras.ulisboa.pt/uploads/textos/437_Aires.pdf >. Acesso em 18 de junho de 2015.

HOMO LITERATUS. Tradução Literária: papo com Carola Saavedra sobre traduzir do alemão, 19 de maio de 2014. Disponível em: <http://homoliteratus.com/tradacaoliterariaalemao/>. Acesso em: 29 de novembro de 2015.

KÖNIG, J. Es war eine ganze Generation. Deutschlandradio Kultur, 13 de agosto de 2009. Disponível em: <http://www.deutschlandradiokultur.de/eswar-ja-eine-ganze-generation.954.de.html?dram:article_id=144514>. Acesso em 11 de junho de 2015.

LEITE, F. L. Além da tortura. Mídia sem Máscara, 08 de fevereiro de 2012. Disponível em: <http://www.midiasemmascara.org/artigos/movimento-revolucionario/12804-alem-da-tortura.html>. Acesso em 29 de novembro de 2015.

MELLO, R. Carola Saavedra: a língua portuguesa é minha casa. Saraiva Conteúdo, 02 de agosto de 2010. Disponível em:

$<$ http://www.saraivaconteudo.com.br/Entrevistas/Post/10369>. Acesso em 28 de novembro de 2015.

MESCHONNIC, H. Poética do traduzir, não tradutologia. In Viva Voz. FALE, Belo Horizonte, UFMG, 2009. (Três traduções interlinguais por: Márcio Weber de Faria (espanhol); Levi F. Araújo (inglês); Eduardo Domingues (português). Disponível em: 
<http://150.164.100.248/vivavoz/data1/arquivos/poeticadotraduzir-site.pdf>. Acesso em 23 de junho de 2015.

MICHAHELLES, K. Entre escrita e tradução. Humboldt - Revista Digital, 2013. Disponível em:

<http://www.goethe.de/wis/bib/pri/hmb/the/159/pt11290484.htm>. Acesso em 30 de novembro de 2015.

MICOTTI, M. C. O. Alfabetização. Propostas e práticas pedagógicas. 2012. Disponível em:

$<$ http://docslide.com.br/documents/alfabetizacao-propostas-e-praticaspedagogicas-macecilia-omicotti-contexto.html> Acesso em 30 de novembro de 2015.

MÜLLER, H. Atemschaukel. Frankfurt am Main: Fischer Verlag, 2009. Tudo o que eu tenho trago comigo. Trad. Aires Graça. Dom Quixote: Alfragide, 2010. . Tudo o que tenho levo comigo. Trad. Carola Saavedra. São Paulo: Companhia das Letras, 2011.

NEUMANN, G. Herta Müller. Autora romena? De língua alemã? Prêmio Nobel? IV CIELLA, Congresso Internacional de Estudos Linguísticos e Literários na Amazônia, 2013.

NUNES, P. Do bilíngue ao tradutor, do enunciado à enunciação: notas sobre uma perspectiva enunciativa do tradutor e da tradução. USP: São Paulo, 2011. Disponível em:

$<$ http://myrtus.uspnet.usp.br/tradterm/site/images/revistas/v18n1/01.TradTerm18_-_Paula_Nunes.pdf $>$. Acesso em 19 de junho de 2015.

RUFINO, M. Prémio Nobel Herta Müller: “A realidade incita-me a escrever pelo lado que me agride". Diário Digital, 17 de setembro de 2012. Disponível em: <http://diariodigital.sapo.pt/news.asp?id_news=592125>. Acesso em 28 de novembro de 2015.

SCHNAIDERMAN, B. Tradução, ato desmedido. Perspectiva: São Paulo, 2011. VON BEYER, S. Ich habe die Sprache gegessen. Der Spiegel, nº 35, 2012. Disponível em: <http://www.spiegel.de/spiegel/print/d-87908042.html>. Acesso em: 10 de junho de 2015. 
Resumo: A obra da escritora Herta Müller já é referência entre os leitores em língua portuguesa por já existirem traduções da língua alemã (língua em que a escritora romena publica suas obras). Caso interessante é a tradução do livro Atemschaukel - talvez o mais importante de Herta Müller - para o português de Portugal e do Brasil quase que simultaneamente (2010 e 2011). Esse fato levou-nos a fazer uma análise das traduções do título do livro para o português, justamente por percebermos aí uma tarefa de grande esforço para os tradutores.

Palavras-chave: Atemschaukel, tradução literária, marcas do tradutor

\begin{abstract}
Herta Müller's work is already well known amongst Portuguese speaking readers since it's already been translated from German (the language in which the Rumanian writer publishes her work) into Portuguese. An interesting case is the translation of Atemschaukel-perhaps Herta Müller's most important book-into European and Brazilian Portuguese almost simultaneously (2010 e 2011). This has led us to produce an analysis of the book's title translations because we realized it meant a great challenge for the translators.
\end{abstract}

Keywords: Atemschaukel, literary translation, translator's marks 